\title{
Highly cultural significant edible and toxic mushrooms among the Tseltal from the Highlands of Chiapas, Mexico
}

\author{
Felipe Ruan-Soto ${ }^{1 *}$
}

\begin{abstract}
The concept of cultural significance and its quantitative evaluation are useful to recognize which mushroom species (both edible and toxic) are the most relevant within a specific community. This work lists the most culturally significant edible and toxic species for the Tseltal groups in the Highlands of Chiapas. It also evaluates whether the composition and significance of these are dissimilar between the different Tseltal communities, proving the hypothesis that the edible and toxic species are not the same nor do they have the same level of significance in different settlements. One hundred and ninetythree interviews were carried out with Tseltal participants regarding edible and toxic mushrooms. The information was analyzed both qualitatively and quantitatively, using multivariate methods. People recognized 25 edible taxa whose names differ across the seven communities. The most frequently mentioned and consumed taxa are Amanita complex. caesarea, Cantharellus complex. cibarius and Agaricus spp. The classification analysis based on the relative frequency of mention for edible species shows a variation pattern explained by the geographic, cultural and linguistic variation between Tseltal groups. For toxic mushrooms, people recognized and assigned names to 17 taxa. Only $17 \%$ of the interviewees assign at least one name to these species. The results show that Tseltal peoples from the Highlands of Chiapas are highly mycophilic. Furthermore, clear differences within the seven Tseltal groups are clear, not only with regards to lexical variations, but also regarding the number of known species, the species that are known and their degree of significance.
\end{abstract}

Keywords: Ethnomycology; Ethnobiology; Traditional Mycological Knowledge.

1 Instituto de Ciencias Biológicas. Universidad de Ciencias y Artes de Chiapas. Libramiento Norte Poniente No. 1150. Colonia Lajas Maciel, C.P. 29039, Tuxtla Gutiérrez, Chiapas, México.

* Corresponding author $\bowtie$. E-mail address: FRS (ruansoto@yahoo.com.mx)

\section{SIGNIFICANCE STATEMENT}

This paper presents the results of detailed aspects of the nomenclature and degree of cultural significance of species deemed edible and toxic by the Tseltal groups of the Highlands of Chiapas. Furthermore, it evaluates the hypothesis that edible and toxic species are dissimilar and carry a different significance in each Tseltal settling. Thus, this manuscript alludes to the most culturally significant edible and toxic wild mushroom species in seven Tseltal communities from this region and whether differences exist between communities sharing ethnicity, particularly regarding composition and degree of significance of mushroom species. The results will undoubtedly be useful to comprehend patterns of usage of edible mushrooms, as well as biological, social and cultural factors relating to toxic species. 


\section{INTRODUCTION}

Out of all the existing species of plants, animals and mushrooms on Earth, human groups prefer to use certain species over others (Camou 2008). This depends on the uses the resource are destined for, their flavor - in case of edible resources -, their ecologic availability, and their economic value (ReyesGarcía et al. 2006), among other features. The cultural significance of a taxon may be defined as the value of the role it plays within a particular culture (Hunn 1982). In this sense, each taxon will have a degree of significance that can range from very high to minimal (Turner 1988).

This does not mean that taxa that have no use are unimportant or lacking in interest (Levi Strauss 1964). People name in detail and classify organisms with any cultural importance, whether this significance is due to use, to them being plagues or because of their toxicity, to mention a few instances. Contrastingly, organisms with little cultural significance are generally recognized only superficially or they are included in residual categories with little or no specificity (Hunn 1982).

In ethnobiology, many cultural significance indexes have been developed to quantitatively evaluate particular taxa within specific cultural domains (Medeiros et al. 2011). Among the most used indexes are those basing their evaluation on informant consensus, that is, the degree of agreement between different persons. These are based on the premise that the greater the importance of a taxon, the more likely it is that it will be mentioned during interviews (Tardío and Pardo de Santayana 2008). The great majority of these indexes have been used to evaluate the significance of utilized resources. There are few examples of evaluations of the significance of organisms that, while relevant, have no direct use, such as toxic species (Ruan-Soto 2018a).

In Mexico, macroscopic mushrooms have been used throughout time to meet different needs, such as nourishment and health. This is especially the case in mycophilic communities in temperate highlands surrounded by conifer and oak forests (Burrola-Aguilar et al. 2012; Robles-García et al. 2018; Ruan-Soto et al. 2013). Different studies have dealt with the composition of greater cultural significance, particularly those that are edible. Taxa such as Amanita sect. caesarea, Lyophyllum decastes (Fr.) Singer, Boletus pinophilus Pilát \& Dermek, Cantharellus cibarius Fr., Agaricus campestris L., Volvariella bombycina (Schaeff.) Singer, and Pleurotus spp. are among the most culturally significant species in central, northern, western, and southern states of Mexico, including Tlaxcala, Estado de México, Oaxaca, Querétaro, Chihuahua, and Jalisco (Alonso-Aguilar et al. 2014; BurrolaAguilar et al. 2012; Haro-Luna 2018; Montoya et al. 2012; Quiñonez-Martínez et al. 2014; RoblesGarcía et al. 2018). However, in Mexico there is also record of a considerable number of intoxications resulting from consumption of toxic wild mushrooms (mycetisms) spanning a great portion of the country (Ramírez-Terrazo et al. 2014); however, little attention has generally been given to this problem, resulting in a lack of knowledge about the causes of these events, including the existing poisonous species and the knowledge people have about them. In Chiapas, several studies have explored the relationship between different indigenous groups and mushrooms (Ruan-Soto and García-Santiago 2013), and some recent studies with Tsotsil groups have begun to explore the most culturally significant edible and toxic species for them (Ruan-Soto 2018a).

The Tseltal are an indigenous group that inhabits the Mexican state of Chiapas. Their language is spoken by just under half a million people (INEGI 2015) distributed across the Highlands of Chiapas and other regions in the state. Many ethnobiological research projects have been carried out with this group, particularly regarding local classification of plants and animals (Berlin et al. 1974; Hunn 1977). Furthermore, some ethnomycological research on this group has recorded different edible and medicinal species, as well as their ways of usage and, prominently, their names and classification (Lampman 2007a; 2007b; Robles-Porras et al. 2007; Shepard et al. 2008). Recently, work has been developed exploring some aspects of the recognized edible and toxic species and a case of poisoning in the communities of Kotolte' and Oxchuc (AlvaradoRodríguez 2010; García-Santiago 2014).

As it has been mentioned, intoxications caused by the consumption of wild mushrooms have been an issue of concern in Chiapas, and there have been studies delving into this phenomenon as well as the related health-illness processes and the medical attention in mycetisms (Ruan-Soto 2018b; 2018c). In response to this situation, government entities in charge of health, along with academics, have developed mitigation strategies to avoid such tragedies. However, the prevention actions and responses have been homogeneous and applied similarly all across the Highlands of Chiapas region regardless of cultural variation existing between the communities in it (Ruan-Soto et al. 2012).

In this scenario, the concept of cultural significance and its quantitative evaluation may be useful in recognizing which species (both edible and toxic) are of greater relevance, and hence most worthy of attention, to the people in specific communities (Albuquerque et al. 2006). For wild mushrooms specif- 
ically, different studies carried out in central Mexico have proven that even when communities share forests, the most culturally significant species may differ between them (Alonso-Aguilar et al. 2014; Montoya et al. 2012), and that this may even happen within the same indigenous group (Moreno-Fuentes 2002).

This work lists the edible and toxic mushroom taxa with the greatest cultural significance for Tseltal groups in the Highlands of Chiapas, exploring whether differences exist between Tseltal communities regarding the species they mention and their degree of significance.

\section{MATERIAL AND METHODS}

\section{Study area}

The Highlands of Chiapas is one of seven physiographic regions in the state of Chiapas. It is located in the central part of the state between $16^{\circ} 30^{\prime}$ and $17^{\circ} 00^{\prime}$ north latitude and $92^{\circ}$ and $93^{\circ}$ west longitude (Robles-Porras et al. 2006) (Figure 1). It is a karstic mountainous area with multiple gullies and hills, containing moderately deep brown clay soils derived from limestone and extrusive volcanic rocks (Quintana-Ascencio and González-Espinosa 1993). It has altitudes ranging from 800 to 2,800 m.a.s.l. and a temperate sub-humid climate $\left[\mathrm{CW}_{2}, \mathrm{Cm}\right.$ y $\mathrm{C}(\mathrm{A}) \mathrm{w}$, with an average annual temperature ranging between 13 and $22^{\circ} \mathrm{C}$ and a rainfall range between 1,300 and $2,200 \mathrm{~mm}$. Heavy rainfall happens mainly from May until October. Frosts are common from December to February (Enríquez et al. 2006; Nepomuceno and Ishiki 2010; QuintanaAscencio and González-Espinosa 1993). In general, the western slope of the region, which is adjacent to the central depression of Chiapas, is drier than the eastern slope (Breedlove 1981). The vegetation is a mosaic of pine and oak forests and, to a lesser extent, pine-oak forests, cloud forests and lowland deciduous forests in the lower lands (Nepomuceno e Ishiki 2010; Quintana-Ascencio y González-Espinosa 1993).

The region contains 17 municipalities spanning $3,723 \mathrm{~km}^{2}$ (INAFED 2005) and it houses 645,099 inhabitants, $57 \%$ of which are indigenous (INEGI 2015). The main economic activities are season agriculture, extensive livestock breeding of sheep, commerce, mining, and tourism, as well as forest exploitation, mainly extraction of wood for construction and firewood, and coal (Enríquez et al. 2006; Quintana-Ascencio y González-Espinosa 1993).

The western portion of the region is inhabited by Tsotsil groups, while the eastern portion is inhabited by Tseltal groups. Tseltal is a language belonging to the Mayan linguistic family; in particular, it belongs to the Tseltalan group in the western branch of this family (Kaufman 1974) (Figure 1).

Specifically, this study was carried out in the main towns of the municipalities Amatenango del Valle (located between $16^{\circ} 32^{\prime} \mathrm{N}$ and $92^{\circ} 26^{\prime} \mathrm{W}$, with an altitude of 1,810 m.a.s.l., with pine-oak forests predominantly and a population of 3,351 people), Oxchuc (located between $16^{\circ} 47^{\prime} \mathrm{N}$ and $92^{\circ} 23^{\prime} \mathrm{W}$, with an altitude of 1,310 m.a.s.l., a vegetation of pine-oak forests and lowland forest, and a population of 15,454), Tenejapa (located between $16^{\circ} 49^{\prime} \mathrm{N}$ and $92^{\circ} 30^{\prime} \mathrm{W}$, with an altitude of 2,060 m.a.s.l., a vegetation of pine-oak forests and a population of 1,692), and Teopisca (located between $16^{\circ} 33^{\prime} \mathrm{N}$ and $92^{\circ} 28^{\prime}$ $\mathrm{W}$, with an altitude of 1,800 m.a.s.l., a vegetation of pine-oak forests, and a population of 11,159), as well as the locations El Madronal within the Amatenango del Valle municipality (located between $16^{\circ} 30^{\prime} \mathrm{N}$ and $92^{\circ} 26^{\prime} \mathrm{W}$, with an altitude of 1,842 m.a.s.l. and a population of 414) and Aguacatenango in the Carranza municipality (located between $16^{\circ} 28^{\prime} \mathrm{N}$ and $92^{\circ} 24^{\prime} \mathrm{W}$, with an altitude of 1,729 m.a.s.l. and a population of 2,165) (INAFED 2005). In all the sites, the dominant language is Tseltal, with the exception of Villa Las Rosas and Teopisca, where Spanish is the dominant language.

\section{Methods}

Firstly, before fieldwork begun, we requested consent by the political and traditional authorities of all the sites where the study was carried out to interview people willing to participate and publish the results and images of the research. Furthermore, previous consent was requested from each participant before the interview begun. All fieldwork was carried out following the lineaments recommended by the Ethics Code of the Latin American Society of Ethnobiology (Sociedad Latinoamericana de Etnobiología SOLAE) (Cano-Contreras et al. 2016).

Fieldwork was carried out between July and November 2019. Structured and semi-structured interviews were carried out according to what Bernard (1995) proposes. The 193 interviewees were randomly chosen following the criteria that they be over 18 and native Tseltal speakers. In total, 27 people from Aguacatenango, 30 from Amatenango del Valle, 20 from El Madronal, 30 from Tenejapa, 25 from Teopisca, 31 from Oxchuc, and 30 from Villa Las Rosas were interviewed. The interviews were done in Spanish with simultaneous translation by Tseltal-speaking interpreters. Whenever possible, the semi-structured interviews were recorded for later translation. 


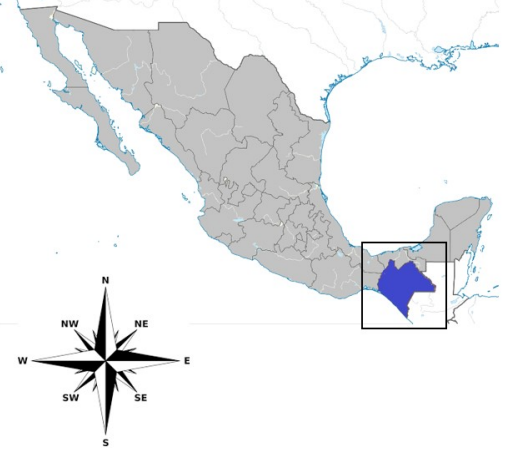

Studied communities

1. Amatenango del Valle

2. El Madronal

3. Aguacatenango

4. Teopisca

5. Villa Las Rosas

6. Tenejapa

7. Oxchuc

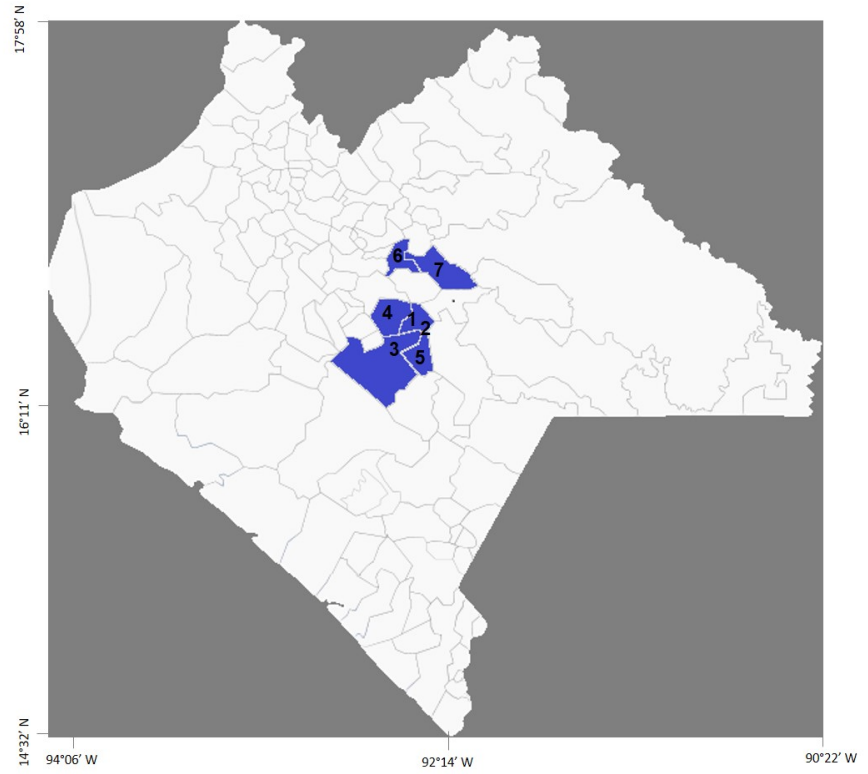

Figure 1. Study area, the Highlands of Chiapas, Mexico.
The semi-structured interviews were focused mainly on taxonomy and local classification, ethnoecological knowledge and uses of mushrooms, while structured interviews included: a) sociodemographic information (age, native language, location and municipality of the interviewee); b) two free listings in which the interviewees were asked to name the edible and toxic mushrooms they knew; and c) a taxonomic corroboration exercise to establish (or at least obtain a proxy of) the taxonomic identity of the ethnotaxa cited in the interviews. This exercise was done with the help of a photograph catalogue with images of 30 edible ethnotaxa from prior ethnomycological studies in the Highlands of Chiapas and 17 toxic species that have been reported in this region (Alvarado-Rodríguez 2010; Lampmann 2007a; Lampmann 2007b; Mariaca et al. 2008; Shepard et al. 2008; Robles-Porras et al. 2007; Ruan-Soto and García-Santiago 2013; RuanSoto 2014; Ruan-Soto 2018a; 2018b; 2018c). The proportion, size and resolution of the images for the catalogue were chosen according to what Thomas et al. (2007) suggest. Lastly, based on this catalogue, people were asked which species they have eaten.

The qualitative data obtained through the semistructured interviews were analyzed by permanently comparing the analysis categories, according to proposals by Sandoval (2002). Frequency of mention was used like an indicator of cultural significance, both for edible and toxic species. Because of this, the most often cited ethnotaxa were considered the most relevant (Alonso-Aguilar et al. 2014; Montoya et al. 2012; Weller and Romney 1988). The frequency of mention was calculated by adding the total amount of times that each taxon was mentioned by all the interviewees in each community. The relative frequency of mention was obtained by dividing the frequency of mention of each taxon by the maximum frequency of mention obtained in its corresponding community. To explore differences between study sites, the relative frequency of mention of edible and toxic species was calculated and a distance matrix was calculated with these data using the average taxonomic distance method. The resulting values were subjected to a cluster analysis using the UPGMA method and to a Principal Components Analysis (PCA) using NTSYS ver. 2.11x for PC (Rohlf 2005).

\section{RESULTS AND DISCUSSION}

\section{Recognized edible mushrooms and their names}

Collectively, people in the study area recognize at least 25 edible taxa according to the observation of the photograph catalogue (Table 1 ). It is important to point out that there is no homogeneous knowledge about the edibility of all the cited taxa in all seven communities. Only 10 taxa are recognized as edible in all the studied communities. Other taxa, such as 
Table 1. Edible and toxic species recognized by the interviewees in the seven studied Tseltal communities from the Highlands of Chiapas and their given names.

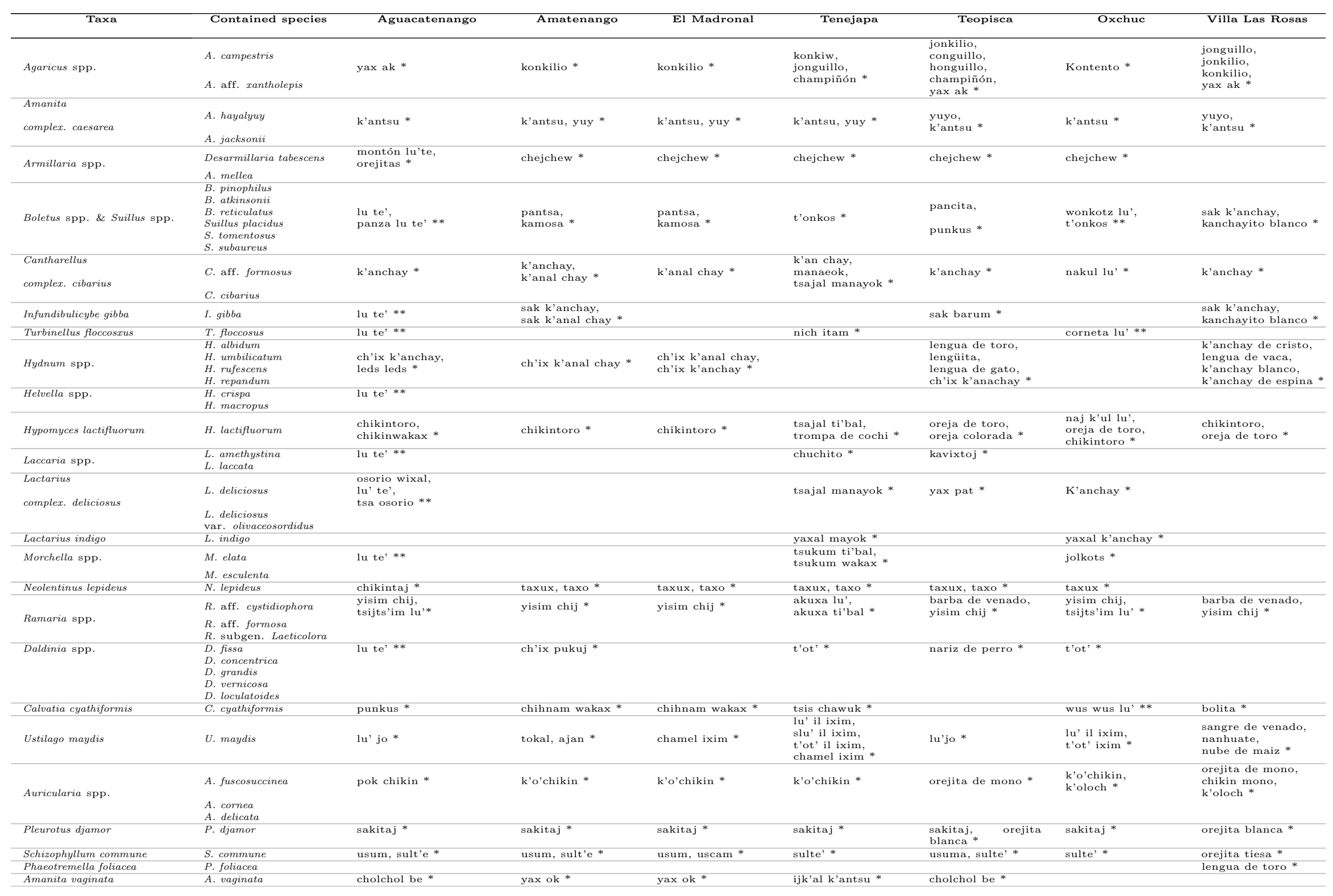




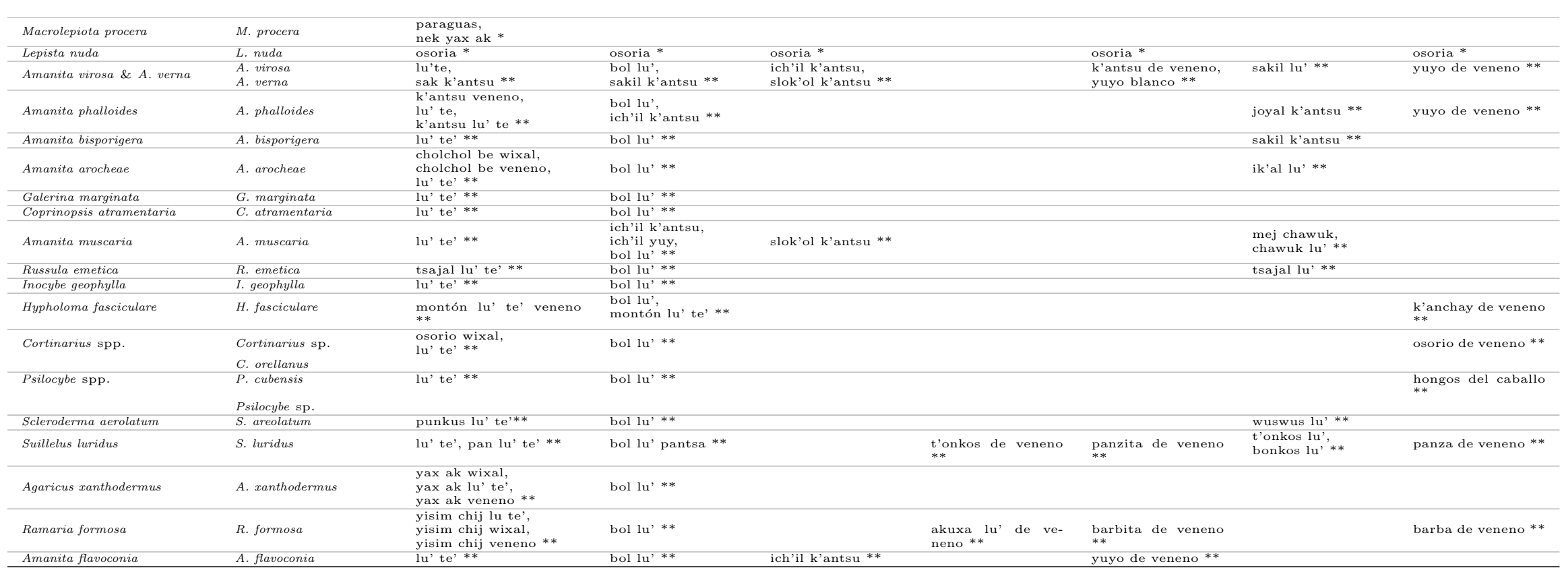


Hydnum spp. or Lepista nuda (Bull.) are deemed edible in most communities, but are not cited in others, such as Oxchuc and Tenejapa. Furthermore, taxa like Boletus spp., Suillus spp. or Calvatia cyathiformis (Bosc) Morgan are recognized as edible in six communities, but deemed toxic in Aguacatenango. The same is true for taxa like Infundibulicybe gibba (Pers.) Harmaja, Turbinellus floccosus (Schwein.) Earle ex Giachini \& Castellano, Laccaria spp., Lactarius complex. deliciosus, Morchella spp., and Daldinia spp., which, in spite of being edible, are considered toxic in at least one community (Figure 2).

Lampman (2007b) reports 19 edible species that are recognized by the Tseltal in the main communities from the Oxchuc and Tenejapa municipalities. Furthermore, Alvarado-Rodríguez (2010) pointed out that there are 18 edible species recognized by the Tseltal from Kotolt'e, Tenejapa. García-Santiago (2014) also reports 18 recognized edible species in the main community of the Oxchuc municipality. Lastly, Robles-Porras et al. (2007) state that the Tseltal from the Pak'bilna and Yoshib communities in Oxchuc identify 39 edible mushroom species. While these studies use methodologies that allow a more precise identification of species, and not just ethnotaxa (i.e. in-depth qualitative research, ethnomycological walks in the communities, taxonomic inventories), a comparison with the number of recognized taxa they obtained is useful to measure the common knowledge of edible mushrooms in the study area. The 25 edible taxa reported in this study are closer to the 28 taxa that are reported as edible among the neighboring Tsotsil communities from the Highlands of Chiapas (Ruan-Soto 2018a).

On the other hand, it is relatively common for conceptions about the edibility of certain species to differ between communities, even when they are geographically or culturally related (Shepard et al. 2008). An example of this is repotted by Ruan-Soto (2014) and Ramírez-Terrazo (2009), who point out that Turbinellus floccosus is deemed edible in Antelá, a community of Tojol-ab'al origins that is adjacent to the National Park Lagunas de Montebello in Chiapas, while it is conceived as a toxic species in Tziscao, a Chuj community less than $5 \mathrm{~km}$. (3.1 mi.) from the first. Furthermore, Moreno-Fuentes (2002) reports the local conception of Boletus spp., a widely used edible species in Mexico and many parts of the world, as a toxic species (Boa 2005; Garibay-Orijel and Ruan-Soto 2014).

Of all the recognized local generic taxa, $52 \%$ correspond one-to-one to a Linnaean species (Berlin et al. 1973) (Table 1). The rest of the cited taxa include different species sharing a similar morphology, as is the case of Amanita complex. caesarea, which includes at least A. hayalyuy D. Arora \& G.H. Shepard and A. jacksonii Pomerl., or the taxa Boletus spp./Suillus spp., which includes species from different genera like $B$ pinophilus, B. atkinsonii Peck, $B$. reticulatus Schaeff., S. placidus (Bonord.) Singer, $S$. tomentosus Singer, and S. subaureus (Peck) Snell. In any case, the species that were proposed as part of the ethnotaxa used in the interviews are a product of a bibliographical revision of works carried out in the Tseltal area (Alvarado-Rodríguez 2010; BautistaGonzález 2013; García-Santiago 2014; Lampman 2007a; Lampman 2007b; Robles-Porras et al. 2006; Robles et al. 2007; Ruan-Soto 2014; Shepard et al. 2008). However, as Ruan-Soto (2018b) points out, it is very likely that a greater ethnomycological collection effort, along with more detailed taxonomic studies (particularly considering molecular features), would surely make the number of species contained within the ethnotaxa grow. In general, we can appreciate that there are scarce ethnomycological studies that incorporate molecular techniques in the process of taxonomic identification of the specimens that people collect in the field, but when they are used, it is possible to characterize a very high number of species, regardless of the degree of mycophilia of the community or region in question (e.g. Kotowski 2019).

The names that the taxa receive across the seven studied Tseltal communities differ. Only K'antsu, used to dessignate Amanita complex. caesarea, is the same in all communities. Other taxa, such as osoria (Lepista nuda), sakitaj (Pleurotus djamor (Rumph. ex Fr.) Boedijn), or k'anchay (Cantharellus complex. cibarius) stand out as ethnotaxa that are homogenously named across most communities. In general, the names assigned to mushrooms have to do with morphological description of characteristic structures (e.g. ch'ix k'anchay means "spiny k'anchay" referring to the spiny hymenium in $\mathrm{Hy}$ dmun species), animal body parts (e.g. yisim chij, meaning "deer beards" because of the ramified aspect of the species in the genus Ramaria), or the habitat they are found in (e.g. cholchol be, which means "placed upon the road", because of the locations in which Amanita vaginata (Bull.) Lam. can generally be found). Some names, like konkilio appear to be loans from Spanish names, jonguillo in this case. Some of the names are a mix of Tseltal and Spanish words, such as chikin toro (Hypomyces lactifluorum (Schwein.) Tul. \& C. Tul.) which means "bull's ear" (chikin means ear in Tseltal, toro means bull in Spanish). Just a few names in Spanish were cited, some examples are lengua de vaca (Hydnum spp.) or sangre de venado (Ustilago maydis (DC.) Corda); these names were mentioned mostly in the communities Villa Las Rosas and Teopisca, towns 


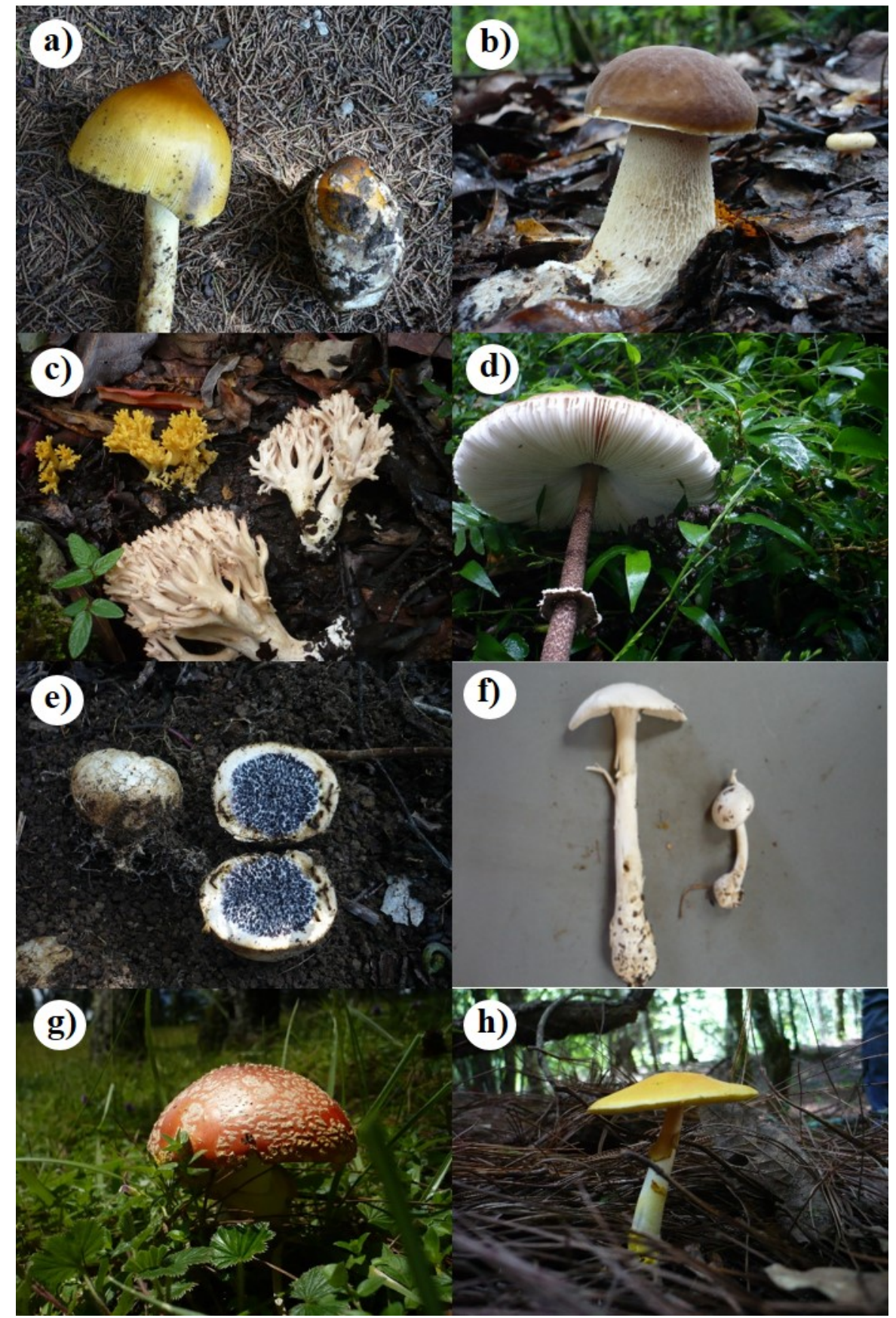

Figure 2. Some Edible and Toxic mushrooms from Tseltal communities in the Higlands of Chiapas. Edible: a) Amanita hayalyuy, b) Boletus pinophilus, c) Ramaria spp., d) Macrolepiota procera. Toxic: e) Scleroderma areolatum, f) Amanita bisporigera, g) Amanita muscaria, h) Amanita flavoconia.

with higher populations and where Spanish is the dominant language. Even though Tseltal is the indigenous language with most speakers in Chiapas, its transmission is receding, particularly in the bigger, more urbanized towns, where Spanish becomes the socializing language. Villa Las Rosas is an example of this; according to Polian (2018), Tseltal has reached a critical point of displacement, since only the elderly continue to speak it.

According to Turner (1988), the level of cultural significance of different taxa may be recognized through the linguistic analysis of local systems of taxonomy and classification. In such an analysis, the fact that a single name is present in different communities with distinct dialectal varieties of Tseltal could indicate a high cultural significance for those 
species. There are even names, such as chejchew, k'anchay, k'antsu, or sakitaj, which are present in other Mayan languages, like Tsotsil. Both Tseltal and Tsotsil are within the Tseltalan language group in the western branch of Mayan languages (Kaufman 1974). In Ruan-Soto's work (2018a) the terms k'antsu and sakitaj were reported to be found in other Mayan languages, such as Mam, Tojol-ab'al and Chuj, all of which are within the western branch of Mayan languages, which might be an indicator of the longstanding cultural significance of these taxa.

\section{Edible mushrooms with high cultural significance: frequency of mention and percentage of consumption}

In general, considering the seven highlander Tseltal communities that were visited, the interviewees mentioned 24 edible species in their free listings. The most frequently mentioned taxa were Amanita complex. caesarea (125 mentions), Cantharellus complex. cibarius (111 mentions) and Agaricus spp. (97 mentions) (Table 2). These three species are mentioned by over $50 \%$ of the interviewed population; on the contrary, 10 species are named by less than $10 \%$ of the population. In average, the interviewees cited $4.55 \pm 2.3$ species, the median is 4 , the minimum was 1 and the maximum was 13 cited taxa.

Recent studies carried out with Tsotsil population in the Highlands of Chiapas recorded a very similar number of mentioned edible taxa in free listings (25). Considering this, the indigenous peoples of the Highlands of Chiapas are among the most mycophilous in the country, at least as far as this indicator can measure, since they mention a greater number of edible taxa than other regions with similar vegetation conditions, such as Oaxaca (GaribayOrijel et al. 2006), the Tarahumara Mountain Range (Quiñonez-Martínez et al. 2014), Jalisco (Haro-Luna 2018), or Xalapa (del Moral et al. 2016), which are in the southern, northern, western, and eastern regions of the country respectively. They would only be surpassed by populations from central Mexico, where there is record of over 50 mentioned edible species using this technique (Montoya et al. 2012).

Even when the number of mentioned taxa is similar to what is reported in Tsotsil groups, the average is lower than the 6.24 species mentioned by them (Ruan-Stoo 2018a). Furthermore, the men- tioned species themselves are different. While there are taxa, such as Amanita complex. caesarea and Agaricus spp. that are among the most significant for both groups, taxa such as Cantharellus complex. cibarius and Lepista nuda are very significant to the Tseltal, but not so for the Tsotsil. Contrastingly, taxa like Ramaria spp., which is mentioned by over $50 \%$ of the Tsotsil population (Ruan-Soto 2018a), is barely mentioned by around $13 \%$ of the Tseltal interviewees.

While frequency of mention is an indicator of cultural significance that is often used (Garibay-Orijel et al. 2006; Kotowski et al. 2019; Montoya et al. 2012), not all of the species recognized as edible are consumed by people in reality. In total, considering the seven visited communities, the interviewees consume 25 taxa. The most consumed taxa are Amanita complex. caesarea, Cantharellus complex. cibarius and Agaricus spp., eaten by $78.76 \%, 65.28 \%$ and $62.69 \%$ of people respectively (Table 3 ). In average, the interviewees consume $6.7 \pm 3.3$ taxa, with a median of 7 , a minimum of zero and a maximum of 15 eaten taxa.

Amanita complex. caesarea may be the most frequently mentioned species across all temperate areas in the country (Garibay-Orijel and Ruan-Soto 2014) and whose consumption is also commonplace in many countries where it is greatly appreciated (Boa 2005; Pegler 2002).

There are no ecologic ethnomycology studies that evaluate the productivity of edible species or whether it has varied as a result of their consumption and commercialization. Nonetheless, the interviewees perceive a lower abundance of certain species (such as Amanita complex. caesarea or Neolentinus lepideus) compared to that of 20 or more years ago.

While the mentioned and consumed species generally coincide (with the exception of Turbinellus floccosus, which is consumed, but not mentioned in free listings), the degree of significance they have display some mention-worthy aspects. Seven out of the ten most significant species are the same both in consumption percentage and in frequency of mention, however, Lepista nuda, Armillaria spp. and Neolentinus lepideus (Fr.) Redhead \& Ginns appear among the ten most mentioned, even though their consumption is low. Contrastingly, Ramaria spp., Schizophyllum commune Fr. and Ustilago maydis are not frequently mentioned in free listings, even though they are highly consumed species. 
Table 2. Relative frequency of mention of the edible species in Tseltal communities from the Highlands of Chiapas.

\begin{tabular}{|c|c|c|c|c|c|c|c|c|}
\hline Taxa & $\begin{array}{c}\text { rel FM } \\
\text { Aguacatenango }\end{array}$ & Amatenango & Madronal & Tenejapa & Teopisca & rel FM & $\begin{array}{c}\text { rel FM } \\
\text { Villa Las Rosas }\end{array}$ & $\begin{array}{l}\text { TOTAL } \\
\text { rel FM }\end{array}$ \\
\hline Agaricus spp. & 1.0000 & 0.4667 & 0.8000 & 0.6429 & 0.6800 & 0.0000 & 0.1667 & 0.5026 \\
\hline Amanita complex. caesarera & 0.3333 & 0.7000 & 0.8000 & 0.8929 & 0.7200 & 0.7097 & 0.4667 & 0.6477 \\
\hline Armillariella spp. & 0.4444 & 0.0000 & 0.0500 & 0.7143 & 0.0800 & 0.5484 & 0.0000 & 0.2694 \\
\hline Boletus spp. \& Suillus spp. & 0.0000 & 0.4333 & 0.5000 & 0.1786 & 0.3200 & 0.0323 & 0.0000 & 0.1917 \\
\hline Cantharellus complex. cibarius & 0.7407 & 0.7333 & 0.9500 & 0.2143 & 0.6800 & 0.0000 & 0.9000 & 0.5751 \\
\hline Infundibulicybe gibba & 0.0000 & 0.0000 & 0.0000 & 0.0000 & 0.0400 & 0.0000 & 0.1000 & 0.0207 \\
\hline Hydnum spp. & 0.0000 & 0.1000 & 0.1000 & 0.0000 & 0.1600 & 0.0323 & 0.0000 & 0.0518 \\
\hline Hypomyces lactifluorum & 0.1111 & 0.5333 & 0.5000 & 0.4286 & 0.2400 & 0.3226 & 0.0000 & 0.2953 \\
\hline Laccaria spp. & 0.0000 & 0.0000 & 0.0000 & 0.0000 & 0.0400 & 0.0000 & 0.0000 & 0.0052 \\
\hline Lactarius complex. deliciosus & 0.0000 & 0.0000 & 0.0000 & 0.0000 & 0.0800 & 0.9677 & 0.0000 & 0.1658 \\
\hline Lactarius indigo & 0.0000 & 0.0000 & 0.0000 & 0.0000 & 0.0400 & 0.2258 & 0.0000 & 0.0415 \\
\hline Morchella spp. & 0.0370 & 0.0000 & 0.0000 & 0.1071 & 0.0000 & 0.1613 & 0.0333 & 0.0518 \\
\hline Neolentinus lepideus & 0.1111 & 0.4000 & 0.4000 & 0.1429 & 0.2800 & 0.3871 & 0.0000 & 0.2383 \\
\hline Ramaria spp. & 0.0741 & 0.1333 & 0.1000 & 0.1071 & 0.2800 & 0.1290 & 0.1667 & 0.1399 \\
\hline Daldinia spp. & 0.0000 & 0.0333 & 0.0000 & 0.0714 & 0.0000 & 0.1935 & 0.0000 & 0.0466 \\
\hline Calvatia cyathiformis & 0.4074 & 0.1000 & 0.3500 & 0.0000 & 0.0400 & 0.0323 & 0.0000 & 0.1192 \\
\hline Ustilago maydis & 0.0000 & 0.0000 & 0.0000 & 0.0000 & 0.0000 & 0.0323 & 0.0333 & 0.0104 \\
\hline Auricularia spp. & 0.2593 & 0.1667 & 0.3000 & 0.0714 & 0.0000 & 0.2258 & 0.5000 & 0.2176 \\
\hline Pleurotus djamor & 0.2222 & 0.0667 & 0.0000 & 0.2143 & 0.1600 & 0.0645 & 0.8333 & 0.2332 \\
\hline Schizophyllum commune & 0.0000 & 0.2000 & 0.2000 & 0.2857 & 0.1200 & 0.3548 & 0.0000 & 0.1658 \\
\hline Phaeotremella foliacea & 0.0000 & 0.0000 & 0.0000 & 0.0000 & 0.0400 & 0.0000 & 0.1667 & 0.0311 \\
\hline Amanita vaginata & 0.5926 & 0.0000 & 0.0500 & 0.0000 & 0.0400 & 0.0000 & 0.0000 & 0.0933 \\
\hline Macrolepiota procera & 0.4815 & 0.0000 & 0.0000 & 0.0000 & 0.0000 & 0.0000 & 0.0000 & 0.0674 \\
\hline Lepista nuda & 0.8148 & 0.7667 & 0.5500 & 0.0000 & 0.0400 & 0.0000 & 0.5000 & 0.3731 \\
\hline
\end{tabular}


Table 3. Number and percentage of consumers (number/percentage) of wild edible mushrooms in Tseltal communties from the Highlands of Chiapas.

\begin{tabular}{|c|c|c|c|c|c|c|c|c|}
\hline Taxa & Aguacatenango & Amatenango & Madronal & Tenejapa & Teopisca & Oxchuc & Las Rosas & TOTAL \\
\hline Agaricus spp. & $25 / 92.59$ & $23 / 76.67$ & $16 / 80.00$ & $23 / 76.67$ & $19 / 76.00$ & $1 / 3.23$ & $14 / 46.67$ & $121 / 62.69$ \\
\hline Amanita complex. caesarera & $18 / 66.67$ & $26 / 86.67$ & $18 / 90.00$ & $25 / 83.33$ & $21 / 84.00$ & $22 / 70.97$ & $22 / 73.33$ & $152 / 78.76$ \\
\hline Armillariella spp. & $6 / 22.22$ & $1 / 3.33$ & $1 / 5.00$ & $20 / 66.67$ & $2 / 8.00$ & $20 / 64.52$ & 0.00 & $50 / 25.91$ \\
\hline Boletus spp. \& Suillus spp. & 0.00 & $21 / 70.00$ & $16 / 80.00$ & $9 / 30.00$ & $13 / 52.00$ & 0.00 & $1 / 3.33$ & $60 / 31.09$ \\
\hline Cantharellus complex. cibarius & $19 / 70.37$ & $27 / 90.00$ & $20 / 100.00$ & $11 / 36.67$ & $18 / 72.00$ & $1 / 3.23$ & $30 / 100.00$ & $126 / 65.28$ \\
\hline Infundibulicybe gibba & 0.00 & $9 / 30.00$ & 0.00 & 0.00 & 0.00 & 0.00 & $8 / 26.67$ & $17 / 8.81$ \\
\hline Turbinellus floccosus & $1 / 3.70$ & 0.00 & 0.00 & $2 / 6.67$ & 0.00 & 0.00 & 0.00 & $3 / 1.55$ \\
\hline Hydnum spp. & $5 / 18.52$ & $16 / 53.33$ & $15 / 75.00$ & $2 / 6.67$ & $7 / 28.00$ & $1 / 3.23$ & $10 / 33.33$ & $56 / 29.02$ \\
\hline Hypomyces lactifluorum & $13 / 48.15$ & $22 / 73.33$ & $15 / 75.00$ & $14 / 46.67$ & $10 / 40.00$ & $15 / 48.39$ & $2 / 6.67$ & $91 / 47.15$ \\
\hline Laccaria spp. & 0.00 & 0.00 & 0.00 & $3 / 10.00$ & $1 / 4.00$ & 0.00 & 0.00 & $4 / 2.07$ \\
\hline Lactarius complex. deliciosus & 0.00 & $1 / 3.33$ & 0.00 & $2 / 6.67$ & 0.00 & $31 / 100.00$ & 0.00 & $34 / 17.62$ \\
\hline Lactarius indigo & 0.00 & 0.00 & 0.00 & $5 / 16.67$ & 0.00 & $16 / 51.61$ & 0.00 & $21 / 10.88$ \\
\hline Morchella spp. & 0.00 & 0.00 & 0.00 & $12 / 40.00$ & 0.00 & $9 / 29.03$ & $1 / 3.33$ & $22 / 11.40$ \\
\hline Neolentinus lepideus & $1 / 3.70$ & $23 / 76.67$ & $10 / 50.00$ & $6 / 20.00$ & $7 / 28.00$ & $10 / 32.26$ & 0.00 & $57 / 29.53$ \\
\hline Ramaria spp. & $15 / 55.56$ & $11 / 36.67$ & $9 / 45.00$ & $10 / 33.33$ & $11 / 44.00$ & $6 / 19.35$ & $11 / 36.67$ & $73 / 37.82$ \\
\hline Daldinia spp. & 0.00 & $1 / 3.33$ & 0.00 & $8 / 26.67$ & 0.00 & $11 / 35.48$ & 0.00 & $20 / 10.36$ \\
\hline Calvatia cyathiformis & $13 / 48.15$ & $7 / 23.33$ & $12 / 60.00$ & 0.00 & 0.00 & 0.00 & $5 / 16.67$ & $37 / 19.17$ \\
\hline Ustilago maydis & $22 / 81.48$ & $5 / 16.67$ & $3 / 15.00$ & $10 / 33.33$ & $1 / 4.00$ & $3 / 9.68$ & $14 / 46.67$ & $58 / 30.05$ \\
\hline Auricularia spp. & $14 / 51.85$ & $15 / 50.00$ & $7 / 35.00$ & $8 / 26.67$ & $2 / 8.00$ & $8 / 25.81$ & $26 / 86.67$ & $80 / 41.45$ \\
\hline Pleurotus djamor & $19 / 70.37$ & $7 / 23.33$ & $10 / 50.00$ & $13 / 43.33$ & $7 / 28.00$ & $3 / 9.68$ & $26 / 86.67$ & $85 / 44.04$ \\
\hline Schizophyllum commune & $1 / 3.70$ & $8 / 26.67$ & $14 / 70.00$ & $15 / 50.00$ & $4 / 16.00$ & $17 / 54.84$ & $1 / 3.33$ & $60 / 31.09$ \\
\hline Phaeotremella foliacea & 0.00 & 0.00 & 0.00 & 0.00 & 0.00 & 0.00 & $12 / 40.00$ & $12 / 6.22$ \\
\hline Amanita vaginata & $21 / 77.78$ & 0.00 & $3 / 15.00$ & $3 / 10.00$ & $4 / 16.00$ & 0.00 & 0.00 & $31 / 16.06$ \\
\hline Macrolepiota procera & $13 / 48.15$ & 0.00 & 0.00 & 0.00 & 0.00 & 0.00 & 0.00 & $13 / 6.74$ \\
\hline Lepista nuda & $18 / 66.67$ & $6 / 20.00$ & $1 / 5.00$ & 0.00 & 0.00 & 0.00 & $3 / 10.00$ & $28 / 14.51$ \\
\hline
\end{tabular}




\section{Comparisons between communities}

It is not rare to find scientific texts assuming that ethnoecological knowledge and resource usage practices are homogeneous within a particular indigenous group. With regards to this, it is frequent to find works that extrapolate the findings obtained in a particular community to the rest of the group in question (e.g. Lampman 2004a; Aldasoro et al. 2016). However, among the Tseltal communities from the Highlands of Chiapas that were studied, there are differences, which will be now pointed out.

When the seven visited communities are compared, Teopisca stands out as the community where the most taxa were mentioned (19), while Villa Las Rosas was where the least taxa were cited (11) (Table 2). As for the composition of species in the listings, we can appreciate that only two taxa Amanita complex. caesarea and Ramaria spp. are mentioned in all seven communities. Furthermore, A. complex. caesarea is among the most frequently mentioned taxa: it is the first place in Tenejapa, Oxchuc and Teopisca. Taxa like Cantharellus complex. cibarius. Agaricus spp. and Lepista nuda also appear as highly mentioned species, but only in Aguacatenango, Amatenango, El Madronal, Teopisca, and Villa Las Rosas, while in Tenejapa and Oxchuc other species are among the most mentioned, including Armillaria spp., Lactarius complex. deliciosus and Lactarius indigo (Schwein.) Fr. In fact, the Lactarius species are only mentioned in Tenejapa and Oxchuc. Furthermore, the fact that Pleurotus djamor and Auricularia spp. are two highly mentioned taxa exclusively in Villa Las Rosas stands out (Table 2 and Figure 3).

The classification analysis, based on the relative frequency of mention of the edible mushrooms, shows a variation pattern that is explained by the geographic, cultural, and linguistic space of the Tseltal groups. One of the groups includes Tenejapa and Oxchuc, while the other contains Aguacatenango, Amatenango del Valle, Madronal, Teopisca, and Villa Las Rosas; this last community is the most different from the former four (Figure 4).

The Principal Components Analysis shows that, the Principal Component 1, which explains 33.66\% of the variation, discriminates Oxchuc and Tenejapa from all the other communities. The characters with highest weight were the frequency of mention of the taxa Daldinia spp. and Schizophyllum commune, in addition to Cantharellus complex. cibarius. The Principal Component 2, which explains $60.87 \%$ of variation, discriminates the group including Villa Las Rosas and Oxchuc. The characters with the greater weight are the frequency of mention of the taxa Ustilago maydis, Boletus spp. and Suillus spp., and Pleurotus djamor (Figure 5).

The significance of the edible species in the genus Lactarius, particularly Lactarius indigo, had been previously noted by Shepard et al. (2008), who point out that this species was consumed exclusively in Oxchuc and Tenejapa, but not in other Tseltal communities they studied. In general, the composition of species that are rendered in Tenejapa and Oxchuc are much more similar to those of the Tsotsil communities studied in Ruan-Soto (2018a). In these, the consumption of Armillaria spp., Lactarius complex. deliciosus and Lactarius indigo is frequent, while that of Cantharellus complex. cibarius and Lepista nuda is not, judging by their infrequent or lacking mention (Ruan-Soto 2018a), as opposed to what was found in communities like Aguacatenango, Amatenango del Valle, or El Madronal.

To Polian (2018), Tseltal is a language with moderate dialectal variation, which is evidently distinct in each municipality, that is, it contains "varieties with specific linguistic features, linked to specific geographic regions" (Polian 2018:32). For Tseltal, there are three dialectal zones: northern, central and southern. Oxchuc and Tenejapa belong to the central dialectal zone, while Aguacatenango, Amatenango (and El Madronal) and Villa Las Rosas belong to the southern dialectal zone. This may partly explain the evident divide in the way people from $\mathrm{Ox}$ chuc and Tenejapa relate to mushrooms compared to the rest of the studied communities. Regarding this, each dialectal variety is a reflection of a unique way to conceive and name the world that surrounds each community (De Ávila 2008; Manrique 2000).

On the other hand, species like Pleurotus djamor and Auricularia spp. are highly mentioned in Villa Las Rosas, the lowest altitude community of the set. These taxa are also commonplace in ethnomycological studies developed in tropical lowlands as some of the most significant (Manga 2013), as well as in Tseltal communities settled in a vegetational transition area, such as Kotolt'e in Tenejapa, which has an altitude of 2,400 m.a.s.l. (Alvaro-Rodríguez 2010) or the Tsotsil communities Pantelho and Chenalhó, in which these taxa are also among the most cited (Ruan-Soto 2018a). This formerly documented preference of lignicolous mushrooms, with a sturdy consistency by inhabitants of tropical lowland communities, is of interest in light of the results of the ordination analyses (Ruan-Soto 2014).

\section{Recognized toxic mushrooms and their names}

Regarding toxic mushrooms, the interviewees from the seven Tseltal communities recognized and assigned names to 17 taxa of toxic mushrooms based 


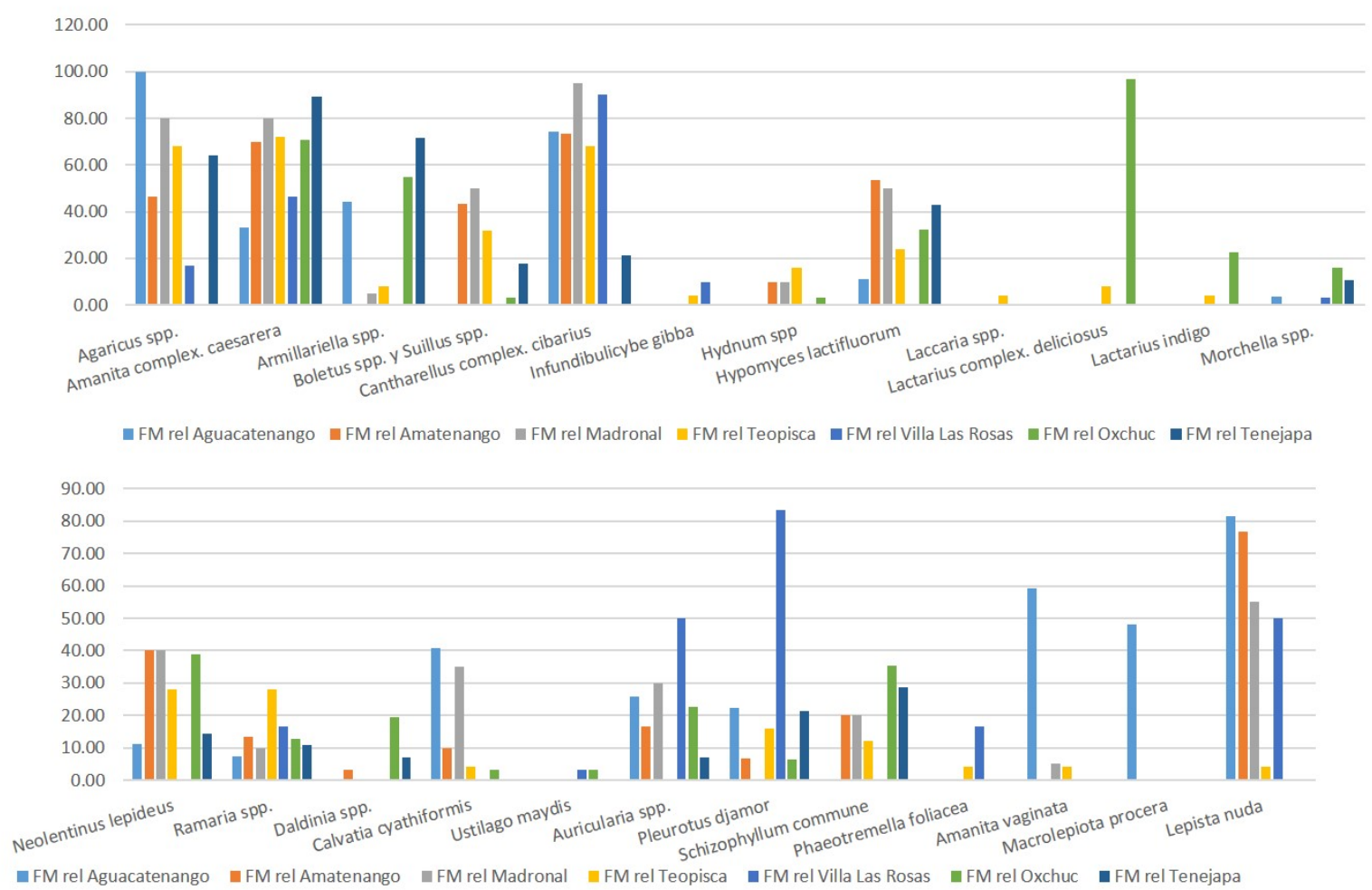

Figure 3. Relative frequency of mention of wild edible mushroom species in Tseltal communities from the Highlands of Chiapas, Mexico.

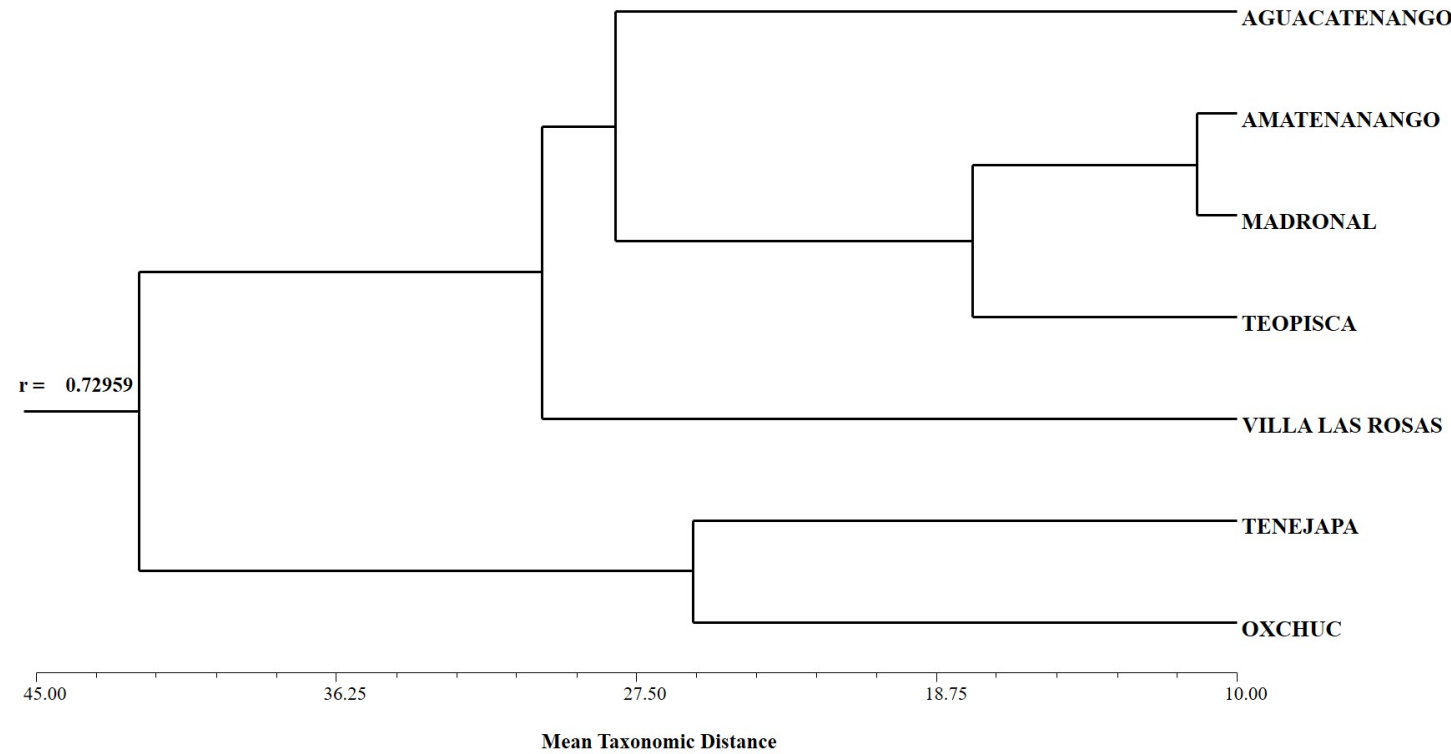

Figure 4. Grouping analysis for the seven Tseltal communities using the average taxonomic distance index based on the relative frequency of mention of the edible mushroom species. 


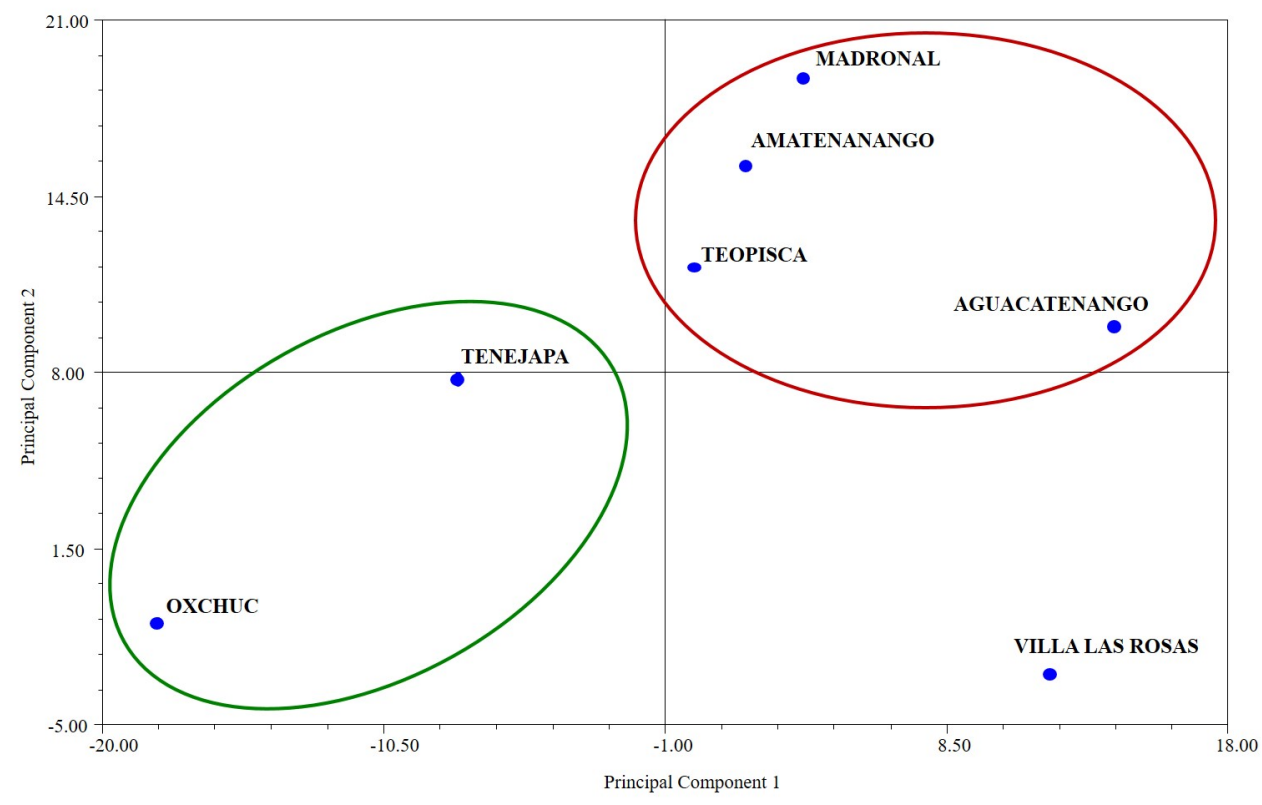

Figure 5. Principal Components Analysis (PCA) of the seven Tseltal communities based on the relative frequency of mention of wild edible mushrooms.

cybe gibba, Turbinellus floccosus, Helvella spp., Lactarius complex. deliciosus, Laccaria spp., and Daldinia spp., which are locally recognized as toxic in some of the communities (Table 1). In a similar work carried out with Tsotsil communities, RuanSoto (2018a) reported the knowledge of 17 taxa that were deemed toxic; however, this conception of typically edible species as locally toxic was not observed.

Some of the names given to toxic mushrooms are based on the names of edible lookalikes with an added adjective that is descriptive of a feature that makes them distinguishable of simply of their toxic nature. For example, Amanita virosa Bertill. and A. verna (Bull.) Lam. are named sakil k'antsu, which means "white k'antsu", in some communities. This name clearly reflects their similitude to the edible species Amanita complex. caesarea, while also pointing out their distinct white color that contrasts with the edible species typical brown-yellow hues. The same taxon was also called yuyo de veneno (poison yuyo) in Spanish. This is repeated for Suillelus luridus and Ramaria formosa (Pers.) Quél., called t'onkos de veneno or panza de veneno and akuxa lu' de veneno or barbita de veneno, respectively, to distinguish them from their edible taxa lookalikes. Furthermore, Cortinarius sp. and Lactarius complex. deliciosus as well as Agaricus xanthodermus Genev. are recognized, in Aguacatenango, as Osorio wixal and yax ak wixal, that is, "osorio's older brother" and "yax ak"s older brother" respectively, thus associating them with Lepista nuda and Agar- icus spp., which are edible. Another prefix that is commonely used in Amatenango and El Madronal is ich'il, which is also used to name a few poisonous plants (Polian 2018). It is part of the names given to Amanita flavoconia and A. virosa / A. verna (ich'il k'antsu), as well as other taxa.

It was remarkable to notice that both in Amatenango and Aguacatenango, all of the toxic mushroom taxa shown in the catalogues were identified, including species reported to be edible in other regions of the state (such as Laccaria spp., Helvella spp., and Turbinellus floccosus, to name a few). However, in many of the cases, the taxa were identified only with the general term lu' te' in Aguacatenango and bol lu' in Amatenango. According to different authors (Hunn 1982; Douglas 1998) only those species of certain interest for a human group will be named and classified in local systematics. The rest of the species are only recognized in very general terms or, as Hunn (1982) puts it, are grouped in "residual categories". In this sense, both lu' te' and bol lu' may be understood as residual categories grouping mushroom species whose edibility is unknown and which, consequently, are locally deemed toxic. Shepard et al. (2008) recorded the use of the term lu te' in Aguacatenango as a way of naming all unknown mushrooms, which are automatically assumed to be toxic.

In different Tseltal communities, the term lu' is used as a component of the names of toxic mushrooms, for example punkus lu te' (Scleroderma areo- 
latum Ehrenb.) in Aguacatenango, bol lu' pantsa (Suillellus luridus (Schaeff.) Murrill) in Amatenango, ik'al lu' (Amanita arocheae Tulloss, Ovrebo \& Halling) in Oxchuc, or akuxa lu' (Ramaria formosa) in Tenejapa. Shepard et al. (1998) pointed out that, in Tenejapa and Aguacatenango, the term lu', which translates literally as "vagina", was used to name toxic mushrooms. Contrastingly, in Oxchuc the term lu' can be considered a higher hierarchy category, since it includes all mushrooms, including both edible and non-edible.

\section{Toxic mushrooms with the highest cul- tural significance}

With regards to the significance of toxic ethnotaxa in the seven studied communities, only 13 taxa were mentioned in free listing exercises (Table 4). In average, the interviewees mention $0.31 \pm 0.7$ taxa, with a median of zero, a minimum of zero and a maximum of four taxa. The species with the greatest cultural significance is Amanita muscaria (L.) Lam., which is mentioned by $10.36 \%$ of the interviewees, followed by Scleroderma areolatum, which is men- tioned by $5.18 \%$ of the interviewed population. The rest of the cited species are recognized by less than $5 \%$ of the interviewees each (Table 4 ). It is interesting to notice the scarcity of people who name toxic species; indeed, only $17 \%$ of the interviewed population assigns at least one name to these species. This pattern of an apparent absence of names for toxic species has been previously reported for Chuj and Tojol-ab'al groups (Ramírez-Terrazo 2009), as well as Tsotsil groups (Ruan-Soto 2018a). However, among the Tseltal, knowledge is even scarcer when we compare the average number of toxic species mentioned with that of Tsotstil groups (1.20 species) (Ruan-Soto 2018a). Amanita muscaria is also the most mentioned toxic species.

Aguacatenango and Oxchuc are the communities in which the greatest number of toxic mushrooms were mentioned (nine taxa). In these communities, the most mentioned species were Amanita arocheae and Amanita muscaria respectively. Villa Las Rosas is second place with six mentioned taxa and Amanita phalloides (Vaill. ex Fr.) Link as the most significant species (Table 4). 
Table 4. Relative frequency of mention (rel FM) of toxic mushroom species in the Tseltal communities from the Highlands of Chiapas.

\begin{tabular}{|c|c|c|c|c|c|c|c|c|}
\hline Taxa & $\begin{array}{c}\text { rel FM } \\
\text { Aguacatenango }\end{array}$ & $\begin{array}{c}\text { rel FM } \\
\text { Amatenango }\end{array}$ & $\begin{array}{c}\text { rel FM } \\
\text { Madronal }\end{array}$ & $\begin{array}{c}\text { rel FM } \\
\text { Tenejapa }\end{array}$ & $\begin{array}{c}\text { rel FM } \\
\text { Teopisca }\end{array}$ & $\begin{array}{l}\text { rel FM } \\
\text { Oxchuc }\end{array}$ & $\begin{array}{c}\text { rel FM } \\
\text { Villa Las Rosas }\end{array}$ & $\begin{array}{l}\text { TOTAL } \\
\text { rel FM }\end{array}$ \\
\hline Amanita virosa $\& \mathcal{G} A$. verna & 0.0370 & 0.0000 & 0.0500 & 0.0000 & 0.0800 & 0.0645 & 0.0333 & 0.0363 \\
\hline Amanita phalloides & 0.0000 & 0.0333 & 0.0000 & 0.0000 & 0.0000 & 0.0323 & 0.1333 & 0.0311 \\
\hline Amanita bisporigera & 0.0370 & 0.0333 & 0.0000 & 0.0000 & 0.0000 & 0.0323 & 0.0000 & 0.0155 \\
\hline Amanita arocheae & 0.1481 & 0.0000 & 0.0000 & 0.0000 & 0.0000 & 0.0323 & 0.0000 & 0.0259 \\
\hline Amanita muscaria & 0.0000 & 0.1333 & 0.0500 & 0.0000 & 0.0400 & 0.4516 & 0.0000 & 0.1036 \\
\hline Russula spp. & 0.0741 & 0.0000 & 0.0000 & 0.0000 & 0.0000 & 0.0323 & 0.0000 & 0.0155 \\
\hline Cortinarius spp. & 0.1111 & 0.0000 & 0.0500 & 0.0000 & 0.0000 & 0.0323 & 0.0667 & 0.0363 \\
\hline Scleroderma aerolatum & 0.0741 & 0.0000 & 0.0000 & 0.0000 & 0.0000 & 0.2581 & 0.0000 & 0.0518 \\
\hline Suillelus luridus & 0.0370 & 0.0000 & 0.0000 & 0.0000 & 0.0400 & 0.1935 & 0.0333 & 0.0466 \\
\hline Agaricus xanthodermus & 0.0000 & 0.0000 & 0.0000 & 0.0000 & 0.0000 & 0.0000 & 0.0333 & 0.0052 \\
\hline Ramaria formosa & 0.0741 & 0.0000 & 0.0000 & 0.0000 & 0.0000 & 0.0000 & 0.0000 & 0.0104 \\
\hline Amanita flavoconia & 0.0000 & 0.0000 & 0.0000 & 0.0000 & 0.0400 & 0.0000 & 0.0000 & 0.0052 \\
\hline
\end{tabular}




\section{CONCLUSION}

According to the findings of this study, the Tseltal groups of the Highlands of Chiapas have a high degree of mycophilia as shown by the high number of edible mushroom species they recognize, name and consume. On the other hand, the fact that they pay very little attention to toxic species is noteworthy. Even though many of the species are recognized, the great majority of the interviewees acknowledge them with terms that are part of residual categories or do not name them at all. The few names given to these species tend to be related to similar looking edible species, that is to say, the knowledge people have in terms of systematics and taxonomy is in relation to edible species, as is that regarding morphology, ecology and distinguishing features. The variations from this "ideal" edible species pattern are catalogued as toxic.

Furthermore, there are clear differences among the seven Tseltal groups that were studied, not only with regards to their lexicology, but also in terms of the number and composition of the known species and their degree of cultural significance. Apparently, these differences may be related to cultural dissimilarities between these groups, whose linguistic variants differ. The surveyed areas include Oxchuc and Tenejapa from the central dialect area, and Amatenango and Aguacatenango from southern dialect area. Furthermore, Villa Las Rosas, despite its belonging to the southern group, is different because of its geography. This is reflected in the most significant edible taxa it was recorded, which are typically tropical, such as Pleurotus djamor, Auricularia spp. and Schizophyllum commune.

The recognition of these patterns is useful to plan strategies aimed at reducing the number of deathly poisonings linked to the consumption of wild mushrooms. These results make it clear that homogeneous strategies for communities with differences in dialect, traditions and ways of understanding the world have a high chance of failure because they overlook these distinctions. A clear characterization of the most culturally significant edible and toxic species is necessary to use this as a basis to generate ad hoc strategies informed by the reality of each community.

\section{ACKNOWLEDGEMENT}

The author would like to acknowledge the Program of Post-doc Scholarships from UNAM for its support and financing to carry out this research. Similarly, he thanks the Centro de Investigaciones Multidisciplinarias sobre Chiapas y la Frontera Sur (CIMSUR-UNAM) for housing him during his post- doc fellowship. Thanks to Dr. Jaime Page Pliego for his logistic support and help with theoretical matters. To Alicia Aguilar Méndez for her collaboration as an interpreter and the translation of the interviews in Tseltal, and to Mr. Manuel Pérez Portillo for his unyielding support in the field. Finally, the author appreciates Dikaryon Language Consultants' help with the translation of the original manuscript in Spanish.

\section{DATA AVAILABILITY}

The data used to support the findings of this study are available from the corresponding author upon reasonable request.

\section{CONFLICT OF INTEREST}

The author has no conflicts of interest to declare.

\section{CONTRIBUTION STATEMENTE}

FRS conceived the presented idea, carried out the experiment and the data analysis, as well as composed the final writing of the manuscript.

\section{REFERENCES}

Albuquerque UP, Lucena RFP, Monteiro JM, Florentino ATN, Almeida CFCBR (2006) Evaluating two quantitative ethnobotanical techniques. Ethnobotany Research and Applications 4:51-60

Aldasoro M, Frutis I, Ramírez E, Nazario C (2016) Los Pjiekakjoo (Tlahuicas) y sus hongos. Ciudad de México, México.

Alonso-Aguilar LE, Montoya A, Kong A, EstradaTorres A, Garibay-Orijel R (2014) The cultural significance of wild mushrooms in San Mateo Huexoyucan, Tlaxcala, Mexico. Journal of Ethnobiology and Ethnomedicine 10:27

Alvarado-Rodríguez R (2010) Conocimiento Micológico Local y micetismo: una aproximación a la etnomicología tzeltal de Kotolte, Tenejapa, Chiapas, México. Tesis de Maestría, El Colegio de la Frontera Sur, San Cristóbal de Las Casas, México

Bautista-González JA (2013) Conocimiento tradicional de hongos medicinales en seis localidades diferentes del país. Tesis de licenciatura, Facultad de Ciencias de la Universidad Nacional Autónoma de México, México D.F., México. 
Berlin B, Breedlove D, Raven H (1974) Principles of Tzeltal Plant Classification: An Introduction to the Botanical Ethnography of a Mayan-Speaking People of Highland Chiapas. Elsevier Academic Press, New York, USA.

Berlin B, Breedlove D, Raven P (1973) General principles of classification and nomenclarure in Folk Biology. American Anthropologist 75:214242 .

Bernard R (1995) Research methods in anthropology. 1a ed. Altamira Press, Lanham, USA.

Boa E (2004) Los hongos silvestres comestibles: perspectiva global de su uso e importancia para la población. FAO, Roma, Italia.

Breedlove DE (1981) Flora of Chiapas. Part 1. Introduction to the Flora of Chiapas. California Academy of Sciences, San Francisco, USA.

Burrola-Aguilar C, Montiel O, Garibay-Orijel R, Zizumbo-Villarreal L (2012) Conocimiento tradicional y aprovechamiento de los hongos comestibles silvestres en la región de Amanalco, Estado de México. Revista Mexicana de Micología 35:1-16.

Camou A (2008) Los recursos vegetales en una comunidad raramuri: aspectos culturales, económicos y ecológicos. Tesis de doctorado, Centro de Investigaciones en Ecosistemas de la Universidad Nacional Autónoma de México, Ciudad de México, México.

Cano-Contreras E, Medinaceli A, Sanabria O, Argueta A (2016) Código de Ética para la investigación, la investigación-acción y la colaboración etnocientífica en América Latina. Etnobiología 14(supl. l):22-27.

De Ávila A (2008) La diversidad lingüística y el conocimiento etnobiológico. In: CONABIO (ed) Capital natural de México Vol. I: Conocimiento actual de la biodiversidad. 1 edn. Conabio, México D.F., pp. 497-556.

Del Moral P, Contreras A, Medel R, Ruan-Soto F (2016) Hongos comestibles del cafetal. 1a ed. Café in Red, Xalapa, México.

Douglas M (1998) Estilos de pensar. Gedisa, Barcelona, España.

Enríquez P, Mariaca R, Retana O (2006) Uso medicinal de la fauna silvestre en Los Altos de Chiapas, México. Interciencia 31(7):491-499.

García-Santiago W (2014) Hongos silvestres comestibles: su papel en los esquemas alimentarios de los pobladores de Oxchuc, Chiapas,
México. Tesis de maestría, El Colegio de la Frontera Sur, San Cristóbal de Las Casas, México.

Garibay-Orijel R, Ruan-Soto F (2014) Listado de los hongos silvestres consumidos como alimento tradicional en México. In: MorenoFuentes A, Garibay-Orijel R (eds) La Etnomicología en México. Estado del Arte. Red de Etnoecología y Patrimonio Biocultural (CONACYT)-Universidad Autónoma del Estado de Hidalgo-Instituto de Biología UNAM-Sociedad Mexicana de MicologíaAsociación Etnobiológica Mexicana A.C.-Grupo Interdisciplinario para el Desarrollo de la Etnomicología en México-Sociedad Latinoamericana de Etnobiología, México D.F., pp. 91-112.

Garibay-Orijel R, Cifuentes J, Estrada-Torres A, Caballero J (2006) People using macro-fungal diversity in Oaxaca, Mexico. Fungal Diversity 21:41-67.

Haro-Luna MX (2018) Etnomicología de los wixaritari y mestizos de Villa Guerrero, Jalisco. Tesis de maestría, Universidad de Guadalajara, Guadalajara, México.

Hunn E (1982) The utilitarian factor in folk biological classification. American Anthropologist 84:830-47.

Hunn E (1977) Tzeltal folk zoology. The classification of discontinuities in nature. 1a ed. Academic Press, New York, USA.

INAFED (2005) Estado de Chiapas. Enciclopedia de los Municipios de México. Accessed 1 march 2019 .

INEGI (2015) Principales resultados de la Encuesta Intercensal, 2015: Chiapas. INEGI, Aguascalientes, México.

Kaufman T (1974) Idiomas de Mesoamérica. 1a ed. Editorial José de Pineda Ibarra - Ministerio de Educación, Guatemala, Guatemala.

Kotowski M, Pietras M, Luczaj L (2019) Extreme levels of mycophilia documented in Mazovia, a region of Poland. Journal of Ethnobiology and Ethnomedicine 5:12.

Lampman A (2007a) General Principles classification among the tzeltal maya of Chiapas, México. Journal of Ethnobiology 27(1):11-27.

Lampman A (2007b) Etnomycology: Medicinal and edible mushrooms of tzeltal Maya of Chiapas Mexico. International Journal of Medicinal Mushrooms (9):1-5.

Lévi Strauss C (1964) El pensamiento salvaje. 1a ed. Fondo de Cultura Económica, México D. F., 
México.

Manga J (2013) Importancia cultural de los hongos comestibles y procesos de migración en el ejido Flor de Marqués, Marqués de Comillas, Chiapas. Tesis de Licenciatura, Facultad de Ciencias Biológicas de la Universidad de Ciencias y Artes de Chiapas, Tuxtla Gutiérrez, México.

Manrique L (2000) Lingüística histórica. In: Manzanilla L, López Luján L (coords.) Historia antigua de México Volumen I: El México antiguo, sus áreas culturales, los orígenes y le horizonte Preclásico. INAH-UNAM-PORRUA, México D.F., pp. 53-93.

Mariaca R, Ruan-Soto F, Cano-Contreras EJ (2008) Conocimiento tradicional de Ustilago maydis en cuatro grupos mayenses del Sureste de México. Etnobiología 6:9-23.

Medeiros M, Da Silva P, Albuquerque UP (2011) Quantification in ethnobotanical research: an overview of índices used from 1995 to 2009. Sitientibus serie Ciencias Biológicas 11(2):211-230.

Montoya A, Torres-García E, Kong A, EstradaTorres A, Caballero J (2012) Gender differences and regionalization of the cultural significance of wild mushrooms around La Malinche volcano, Tlaxcala, México. Mycologia 104(4): 826834 .

Moreno-Fuentes A (2002) Estudio etnomicológico comparativo entre comunidades rarámuris de la Alta Tarahumara, en el estado de Chihuhua. Tesis de doctorado, Facultad de Ciencias de la Universidad nacional autónoma de México, Ciudad de México, México.

Nepomuceno A., Ishiki M (2010) Las plantas empleadas para el tratamiento de las infecciones respiratorias en los altos de Chiapas (México). Etnobiología 8:11-30.

Pegler DN (2002) Useful Fungi of the World: Caesar's mushroom and the Christmas mushroom. Mycologist 16:140-141.

Polian G (2018) Diccionario multidialectal del tseltal. 1a ed. INALI - CIESAS, México D.F., México.

Quintana-Ascencio P, González-Espinosa M (1993) Afinidad fitogeográfica y papel sucesional de la flora leñosa de los bosques de pino-encino de Los Altos de Chiapas, México. Acta Botánica Mexicana 21:43-57.

Quiñónez-Martínez M, Ruan-Soto F, AguilarMoreno IE, Garza-Ocañas F, Lebgue-Keleng T,
Lavín-Murcio PA, Enríquez-Anchondo ID (2014) Knowledge and use of edible mushrooms in two municipalities of the Sierra Tarahumara, Chihuahua, Mexico. Journal of Ethnobiology and Ethnomedicine 10:67.

Ramírez-Terrazo A (2017) Importancia cultural de los hongos no comestibles en dos comunidades de las faldas del volcán La Malintzi, Tlaxcala. Tesis de Maestría, Instituto de Biología de la Universidad Nacional Autónoma de México, Ciudad de México, México.

Ramírez-Terrazo A (2009) Estudio etnomicológico comparativo entre dos comunidades aledañas al Parque Nacional Lagunas de Montebello, Chiapas. Tesis de Licenciatura, Facultad de Ciencias de la Universidad Nacional Autónoma de México, Ciudad de México, México.

Ramírez-Terrazo A, Montoya A, Caballero J (2014) Una mirada al conocimiento tradicional sobre los hongos tóxicos en México. In: MorenoFuentes A, Garibay-Orijel R (eds.) La Etnomicología en México. Estado del Arte. Red de Etnoecología y Patrimonio Biocultural (CONACYT)Universidad Autónoma del Estado de HidalgoInstituto de Biología UNAM-Sociedad Mexicana de Micología-Asociación Etnobiológica Mexicana A.C.Grupo Interdisciplinario para el Desarrollo de la Etnomicología en México-Sociedad Latinoamericana de Etnobiología, México D.F., pp. 116-145.

Reyes-García V, Valdez V, Tanner S, McDade T, Huanca T y Leonard WR (2006) Evaluating indices of traditional ecological knowledge: a methodological contribution. Journal of Ethnobiology and Ethnomedicine 2:21.

Robles-Porras L, Huerta G, Andrade-Gallegos R, Ángeles H (2007) Conocimiento tradicional sobre los macromycetes en dos comunidades de Oxchuc, Chiapas, México. Etnobiología 5:21-35.

Robles-Porras L, Ishiki M, Valenzuela R (2006) Inventario preliminar de los macromicetos en los Altos de Chiapas, México. Polibotanica 21:89-101.

Robles-García D, Suzán-Azpiri H, Montoya-Esquivel A, García-Jiménez J, Esquivel-Naranjo E, Yahia E, Landeros-Jaime F (2018) Ethnomycological knowledge in three communities in Amealco, Quéretaro, México. Journal of Ethnobiology and Ethnomedicine 14:7.

Rohlf FJ (2005) NTSYS-pc: Numerical Taxonomy and Multivariate Analysis System, Version 2.2. 1a ed. Exeter Software, New York, USA. 
Ruan-Soto F (2018a) Sociodemographic differences in the cultural significance of edible and toxic mushrooms among Tsotsil towns in the Highlands of Chiapas, Mexico. Journal of Ethnobiology and Ethnomedicine 14:32.

Ruan-Soto F (2018b) Intoxicaciones por consumo de hongos silvestres entre los tsotsiles de Chamula, Chiapas, México. Sociedad y ambiente 17:7-31.

Ruan-Soto F (2018c) Recolección de hongos comestibles silvestres y estrategias para el reconocimiento de especies tóxicas entre los tsotsiles de Chamula, Chiapas, México. Scientia fungorum 48:1-13.

Ruan-Soto F (2014) Micofilia o Micofobia: Estudio comparativo de la importancia cultural de los hongos comestibles entre grupos mayas de tierras altas y de tierras bajas de Chiapas, México. Tesis de doctorado, Instituto de Biología de la Universidad Nacional Autónoma de México, Ciudad de México, México.

Ruan-Soto F, Caballero J, Martorell C, Cifuentes J, González-Esquina AR, Garibay-Orijel R (2013) Evaluation of the degree of mycophiliamycophobia among highland and lowland inhabitants from Chiapas, Mexico. Journal of Ethnobiology and Ethnomedicine 9:36.

Ruan-Soto F, García-Santiago W (2013) Uso de los Hongos macroscópicos: estado actual y perspectivas. In: CONABIO (ed.) La biodiversidad en Chiapas: Estudio de estado. CONABIOGobierno del Estado de Chiapas, Ciudad de México, pp. 243-258.

Ruan-Soto F, Mariaca R, Alvarado-Rodríguez R
(2012) Intoxicaciones mortales por consumo de hongos: una cadena de errores. Ecofronteras 44:12-14.

Sandoval C (2002) Investigación cualitativa. Programa de especialización teórica, métodos y técnicas de investigación social. 1 ed. ICFES, Bogotá, Colombia.

Shepard GH, Arora D, Lampman A (2008) The Grace of the Flood: Classification and Use of Wild Mushrooms among the Highland Maya of Chiapas. Economic Botany 62(3):437-470.

Tardío J, Pardo de Santayana M (2008) Cultural important indices: a comparative analysis based on the useful wild plants of southern Cantabria (northern Spain). Economic Botany 62(1):24-39.

Thomas E, Vanderbroek I, Van Damme P (2007) What works in the field? A comparison of different interviewing methods in ethnobotany with special reference to the use of photographs. Economic Botany 61(4):376-384.

Turner N (1988) The Importance of a rose: evaluating the cultural significance of plants in Thompson and Lillooet interior Salish. American Anthropologist 90:272-290.

Weller SC, Romney AK (1988) Systematic data collection. 1 ed. Sage Publications, Newbury Park, USA.

Received: 01 June 2020

Accepted: 29 July 2020

Published: 07 August 2020 